\title{
RIGHTS AND REMEDIES OF AN OPERATOR VIS-A-VIS A \\ DEFAULTING NON-OPERATOR UNDER JOINT AND UNIT OPERATING AGREEMENTS
}

\author{
RICHARD H. BARTLETT*
}

\begin{abstract}
"The oil and gas industry is not a law unto itself and must operate within the strictures of the general principles of the law of contract and property." Within this framework, the author examines typical terms and conditions of Joint and Unit Operating agreements with a view to discerning the nature of the operators' rights and remedies as against a defaulting non-operator. Inadequate safeguards within the agreements and inequitable remedies at law are found to exist causing the author to make recommendations as to the drafting of agreements and the enactment of statutory provisions to improve this disadvantageous position.
\end{abstract}

\section{INTERPRETATION}

The cardinal principle governing the interpretation of contracts is that there must be assigned to each word in the contract its plain, ordinary meaning.

The interpretation of contracts employed in the oil and gas industry was recently examined in Canadian Delhi Oil v. Alminex. ${ }^{1}$ Smith C. J.A. in delivering judgement cited Hillas v. Arcos ${ }^{2}$ in holding that in the construction of an operating agreement regard is to be had to the words used in their ordinary plain meaning. Where those words are, in their primary meaning, unambiguous and clear, and that meaning is not controlled by the context and is sensible with reference to extrinsic circumstances, the court ought to give effect to them, even though this meaning may lead, in the opinion of some of the parties, to an absurd result.

The lack of singularity of this decision reflects the trend running throughout this article; the oil and gas industry is not "a law unto itself" and must operate within the strictures of the general principles of the law of contract and property.

\section{RELATIONSHIP OF THE PARTIES}

The "unit operating agreement" is entered into by the working interest owners, and provides for the carrying out of the unit operations that have been authorized by the royalty owners in the unit agreement. The unitization is effected by the unit agreement in such terms as: ${ }^{3}$

On and after the effective date the interests of each royalty owner and each working interest owner in the unitized substances and in the unitized zone are hereby unitized, as if the unitized zone had been included in a single lease executed by the royalty owners as lessors, in favour of the working interest owners, as lessees, and as if the lease had been subject to this Agreement.

The "joint operating agreement" establishes an arrangement whereby two or more parties, each possessed of an undivided interest in the petroleum

\footnotetext{
Teaching Fellow, Osgoode Hall Law School.

Editor's Note: The Canadian Petroleum Law Foundation awards annual prizes for articles on Oil and Gas Law. Mr. Bartlett's article was awarded second prize by the Directors of the Canadian Petroleum Law Foundation for 1971 .

I (1968) 62 W.W.R. 513.

2 [1932] All E.R. 494.

3 Model Oil and Gas Unit Operating Agreement, 1966, Clause 301.
} 
and natural gas rights in a given area of land, will drill for and develop such mineral resources.

The relationship established under both forms of operating agreement necessitates the appointment of a managing party-referred to as the managing-operator or operator. The party appointed as operator is generally the party who owns the largest working interest. In joint operations, control over the operator by the other working interest owners is generally limited to its replacement for default, or challerige if operations are conducted at excessive cost. The unit operator, by contrast, exercises its powers subject to the control of the operating committee: ${ }^{4}$

The Operating Committee shall have and exercise all the rights and powers granted to the Working Interest Owners by the Unit agreement, except to the extent that certain of the said rights and powers are by this agreement specifically delegated to Unit Operator to be exercised by Unit Operator subject to the orders, directions and limitations given or imposed by the Operating Committee.

Most development and operating agreements involve some degree of joint venturing, but it is usual to include clauses stating that the parties are not to be deemed to be a partnership or an association and are not to incur joint liability. In unit operations such a provision may be included in the unit agreement. Such clauses are intended to ensure that parties other than the operator may not be held entirely responsible for liabilities which may be incurred in carrying on operations. It may be agreed that each party shall be separately liable for a portion of the total liability calculated upon the basis of its participating interest. The utility of the provisions is limited as they cannot prevent the relationship of the parties from attracting joint liability if in fact they conduct themselves as a partnership or joint venture. In Canadian Delhi Oil v. Alminex Ltd. ${ }^{5}$ Chief Justice Smith in the Appellate Division of the Supreme Court of Alberta held that a clause negativing both a partnership and association could not avert the attaching of joint liability in the conduct of unit operations.

An effort may also be made to exclude any fiduciary element in the relationship between the parties. An example of such a clause is: ${ }^{6}$

It is not the purpose of this Agreement to create any partnership, mining partnership or joint venture relationship, and neither this Agreement nor the operations conducted under it shall be construed and considered as creating any such relationship.

A positive statement as to the efficacy of such a provision is difficult to discover in the law reports, but it does appear that its potency is limited. Johnson J.A. in delivering judgement in the Appellate Division of the Supreme Court of Alberta in Midcon Oil and Gas Ltd. v. New British Dominion Oil Co. and Brook stated: ${ }^{7}$

If in fact agency is created by the agreement a denial of that fact in the agreement will not prevent it being so.

On appeal to the Supreme Court of Canada ${ }^{8}$ neither the majority nor the minority offered an unequivocal statement on the problem with the majority rejecting the contention that in that instance the parties to

- Id. Clause 501.

supra, n. 1.

- 1 Lewis \& Thompson, Canadian Oil and Gas Law, Form B 4(b) Joint Operation Agreement, Clause 31.

, (1957) 21 W.W.R. 228 at 236.

" [1958] S.C.R. 314. 
the operating agreement stood in a fiduciary relationship. The majority did find, however, that, although no fiduciary relationship existed, the operator did owe the non-operator a "duty to act in good faith" in the negotiation for and in the sale of gas developed from the field.9 Locke J. remarked:10

The principle upon which Keech v. Sandford (1803), 8 Ves. 337 and Ex parte James (1726), Sel. Cas. Ch. 61, were decided has no application to a relationship such as here existed. The reason for the rule applied in these cases as pointed out by Lord Redesdale L.C., Griffin v. Griffin (1804) 1. Sch. and Lef. 352, is a public policy. Keech v. Sandford was an infant's case and Ex parte James that of a purchase by a solicitor to the commission of a bankrupt's estate, where Lord Eldon, after stating the principle that had been applied in the earlier case, said in part (at 345): "This doctrine as to the purchases by trustees, assignees, and persons having a confidential character, stands much more upon general principle than upon the circumstances of an individual case. It rests upon this; that the purchase is not permitted in any case, however honest the circumstances; the general interests of justice requiring it to be destroyed in every instance; as no court is equal to the examination and ascertainment of the truth in much the greater number of cases.' . . . I know of no principle, of either law or equity, which in these circumstances restricted in any manner the liberty of the respondent to take part in the promotion of a company and to acquire shares in that company, in the hope that it might become a possible purchaser of the gas or which could conceivably give any right to the appellant to participate in the purchase or to recover damages, in the absence of bad faith on its part of the nature above suggested. It is impossible, in my opinion, to suggest that any reason of public policy requires the application of the rule in Keech v. Sandford.

The minority judgement was delivered by Rand J.:11

... the operator so developing, exploiting and marketing a jointly owned product for a joint benefit, has reposed in him that reliance and confidence which constitutes a trust relation.

The learned judge cites the rule in Keech v. Sandford and concludes that "the property which he purchased for himself was sufficiently connected with the scope of his duties as a fiduciary so that it was improper for him to purchase it for himself." 12 The dissent attributed some importance to the conflict that arose between the duty of the operator and its interests as a shareholder in the gas purchasing company. This element of the judgement is buttressed by the recent decision of the House of Lords in Boardman v. Phipps where Lord Cohen commented:13

... an agent is liable to account for profits he makes out of trust property if there is a possibility of conflict between his interest and his duty to his principal.

American practice suggests a fiduciary relationship will be readily found in the circumstances of operations and development in the oil and gas industry. Williams and Meyers, in dealing with the fiduciary duty of a managing partner in a joint venture, state: ${ }^{14}$

The managing partner in a joint venture in particular, owes a fiduciary duty to the other participants in the enterprise and is debarred from acquiring for his own benefit beneficial interests in property on the basis of information acquired in the performance of his duties as a manager. He must hold any interests so acquired on constructive trust [Smith v. Bolin, 153 Texas 486, 3 O. and G.R. at 1534]. In a sense, 'joint venture' like constructive trust, is an adjective rather than a substantive concept; its main employment by the courts is to provide a basis on which to find a fiduciary relationship on which to find a constructive trust.

\footnotetext{
Id. at 326.

${ }^{10}$ Id.

"Id. at 329.

12 Id. at 321.

13 [1967] 2 A.C. 46 at 103.

14 2 Oil and Gas Law, 8. 437.1.
} 
The duties of the operator under the agreement are usually specified at some length. Among them is the duty to "initially advance and pay all costs and expenses for the drilling, completing and operating of all the wells ... for the joint account and for the treating, handling, storing and marketing of the petroleum substances obtained therefrom." 15 Corresponding to this duty the agreement requires that "the parties shall reimburse the ... operator for all such costs and expenses in proportion to their ... participations." 16 A financial burden is thus placed upon the operator to fund operations on the joint account. The remedies discussed in this article are an effort to lighten the weight of this burden by ensuring effective redress in the event of fiscal default by a non-operator.

The parties may have agreed upon the terms and conditions upon which the development of oil and gas resources may take place, but yet differ as to a course of action. In recognition of such a possibility joint operating agreements invariably make provision for independent operations. Independent operations consist in the "drilling, deepening, completing, re-working and plugging-back operations of, in and on a well ... by ... a party for its sole account."17 In such operations the party performing the managerial function of an operator is generally the operator under the operating agreement if he is a participating party, otherwise the proposing party adopts that position. The participants rights and duties among themselves in the independent operations are determined as if carried out by all the parties to the operating agreement: 18

As among the participating parties:

(i) the provisions of this operating procedure relating to the rights and duties of the operator, and

(ii) the rights and obligations of non-operators shall apply mutatis mutandis to the conduct of the independent operation and to the operation of the independent well during recovery of costs and penalty under this Article.

\section{AUTHORITY OF OPERATOR RE EXPENDITURE}

The non-operator is generally obliged to reimburse the operator for its share of costs and expenses incurred for the joint account. The authority of the operator to act upon behalf of the joint account is, however, subject to the limitations stated in the operating agreement. Of most importance is the restriction that no single expenditure in excess of a stated sum (usually ten thousand dollars) may be made for the joint account unless approved by each non-operator in writing.

The approval of expenditure required by the agreement is given in the form of an "authorization for expenditure" (AFE). The operator sets out in the AFE its proposed costs for a given operation and sends it to each non-operator. If the non-operator approves the expenditure it signs the AFE and returns it to the operator. The form then constitutes authority under which the operator may incur such expenditure. The operating agreement may allow. the operator to exceed the authorized expenditure on behalf of the joint account by a stated percentage (usually ten per cent). The requirement of written authorization for

\footnotetext{
15 A.A.P.L. Operating Procedure, 1970, Clause 502.

16 Supra, n. 4, Clause 1201.

17 Operating Procedure (Two Party Joint Operations), Clause 1001(2).

18 Supra, n. 15, Clause 1015.
} 
expenditure above a stated sum is not negatived by an arrangement whereby the non-operator advances costs and expenses to the operator on the basis of estimates submitted by the operator.

In unit operations provision is often made for the authorization of a budget of expenditures for a complete year by the operating committee. The Model Unit Oil and Gas Operating Agreement, 1966 states: $^{19}$

The operating committee may approve a budget or any portion thereof or it may conditionally approve any proposed expenditure or it may instruct unit operator to reverse a budget or any portion thereof.

Other exceptions to the general restriction on expenditure in excess of the specified sum found in operating agreements include expenditure necessary for the preservation of life or property and limited expenditure for the full settlement of each damage claim resulting or arising from operations. The authority occasionally bestowed upon the operator to incur expenditure in "operations required to keep the leases in full force and effect and/or is required by any law or regulation" might be regarded as a form of that agency of necessity conferred by other provisions. Such authority is normally limited by a statement that it shall not be construed as authority for the operator to drill a well on the lands without the authorization of the parties.

The authority granted in an operating agreement to the operator to expend money in the event of danger to life or property would seem to be more extensive than that available at common law. Agency of necessity arises at common law: ${ }^{20}$

... by operation of law in certain cases where a person is faced with an emergency in which the property or interests of another are in imminent jeopardy and it becomes necessary in order to preserve the property or interests, to act for that person without authority.

For such an agency to arise it must be impossible, or at any rate impracticable for the agent to communicate with his principals. In the circumstances under which drilling and development of a well take place this requirement might be satisfied, but it would be an infrequent situation and difficult to establish.

The limitations upon expenditure by the operator in excess of a stated sum on behalf of the joint account would seem to apply even in the instance where the non-operator agrees to participate in an undertaking where the cost is unspecified. Such an undertaking might be the setting of casing and completion of a well. In the 1970 A.A.P.L. Operating Procedure, clause 902 provides, re casing point election:

The operator shall give immediate notice to the non-operators when the well has reached the Authorized depth. . . Each non-operator shall then have a period of 24 hours to inform the operator whether it wishes to participate in the cost of setting casing and making a completion attempt. Failure to reply to the notice from the operator shall be deemed an election to participate....

The requirement of an AFE for expenditure does not seem incompatible with Clause 902 . It would seem that the casing point election is merely a preliminary step authorizing completion subject to the costs and expenses involved being authorized.

The relationship between the operator and non-operators may be affected by dealings by the former in excess of his authority with third

\footnotetext{
19 Clause 1202.

20 Bowstead on Agency 29, Article 14 (13th ed. 1968).
} 
parties. The non-operators might be said to have represented that the operator was in a position bearing usual authority, that is that "the principal is liable for all the acts of the agent which are within the authority usually confided to an agent of that character, notwithstanding limitations, as between the principal and the agent, put upon that authority."21 The uniformity of operating agreements and the development of model agreements suggests, however, that it might be concluded that the "usual authority" of an operator in the oil and gas industry is a warrant subject to the restrictions normally found in such agreements.

\section{PROCEDURE FOR PAYMENT}

Under the operating agreements the custom is that the operator initially pays and charges to the account of all the parties all costs and expenses made or incurred with respect to the operations or development and production in accordence with the accounting procedure. Provision may be made for deviation from this norm by permitting the operator to charge non-operators in advance of the costs and expenses being incurred. The usual procedure involves the submission of a request by the operator that each non-operator should advance its estimated share of costs and expenses contemplated in the succeeding month. In subsequent requests the estimated expenditure is adjusted to the actual expenditure.

In the event that a twelve month budget is approved, as provided for in the Model Unit Operating Agreement, 1966, an operating fund may be established from which costs and expenses may be paid as they are incurred. The fund may be created by requiring the parties to advance one twelfth of the approved expenditure (other than for capital items) and is maintained by billing the parties at the end of the month for the actual costs incurred in that month.

\section{GENERAL PRINCIPLES}

The remedies for the breach of the operating agreement by the nonoperator are governed by the general principles of the law of contract. The application of the principles to individual circumstances in oil and gas operations will, of course, vary. It is, however, suggested that generally the remedies available to the operator under the law of contract, apart from the operating agreement, are inappropriate to his needs.

If the breach of the operating agreement by the non-operator in failing to pay costs and expenses when due is such as to entitle the operator to repudiate the contract, then the operator has a choice of either holding the defaulting party to his promise and suing for damages or treating the contract as discharged, refusing to perform further his obligations under the contract, and claiming damages. Such a breach has been described as affecting "the very substance of the contract" 22 and its effect is to "make the performance a totally different performance of the contract from that intended by the parties. ..."23 In considering the nature of the non-operator's breach it might be observed that most operating agreements anticipate a large drilling and development expenditure, and the rationale is that this expenditure will be shared by

\footnotetext{
21 Id. at 63.

22 Wallis, Son \& Wells v. Pratt \& Haynes [1910] 2 K.B. 1003 at 1012 per Moulton L.J.

${ }^{23}$ Hong Kong Fir Shipping Co. v. Kaurasaki Kisen Kaisha [1962] 2 Q.B. 26 at 57 per Sellers L.J.
} 
the parties to the agreement. It is submitted that a mere delay in payment will not constitute so substantial a breach as to entitle the operator to repudiate the agreement vis-a-vis the defaulting non-operator. If the delay in payment is such as to amount to a failure to pay then it will constitute such a breach. Moreover, if the default in payments amounts to refusal to continue to perform the agreement, then such a renunciation would entitle the operator to repudiate the contract. It may be that the breach amounts to a breach of condition by the non-operator; the operator might then repudiate the agreement. Time may be of the "essence," either expressly in the agreement or implied from the circumstances in which oil and gas operations take place. Failure by a nonoperator to pay costs and expenses when due in such an agreement would constitute a breach of condition.

In the event that the operator becomes entitled to repudiate the agreement the worth of this remedy is minimal. It is improbable that the operator wishes to cease development, which such repudiation might involve. The law relating to damages is likely to prevent compensation for the loss of time and the loss in market value of the interest of the operator. Repudiation may be complicated by the presence of parties to the agreement other than the operator and the defaulting non-operator. In that event it would appear that the operator is denied the remedy of repudiating the entire agreement, and operations must continue vis-a-vis the non-defaulting parties under the agreement.

The efficacy of an award of damages may be limited. If the defaulting party is unable to pay the costs and expenses due then he is unlikely to be able to pay satisfactory damages. It may be, however, that his breach of contract is due to an unwillingness, rather than an inability, to pay, or that his incapacity is only temporary.

The object of the law in awarding damages for breach of contract is to put the plaintiff "so far as money can do it ... in the same situation ... as if the contract had been performed." 24 At common law this was interpreted so that the sole remedy for breach of an obligation to pay a sum of money was an action to recover that sum though "[a] man may be utterly ruined by the non-payment of a sum of money on a given day, [and though] the damages may be enormous. . . ."25 Only nominal damages are recoverable for failure to pay money. Recent dicta in the Court of Appeal in England suggest that the rule may not be rigidly followed in the future: Romer L.J. said he was not "as at present advised, prepared to subscribe to the view that in no case can damages be recovered for non-payment of money. . . ."26 Denning L.J. thought that "the only real ground" for the rule was that the consequences of the non-payment were "generally presumed not to be within the contemplation of the parties." 27 It is submitted that despite the doubts surrounding the application of this limitation upon the award of damages, an operator could rarely succeed in gaining an award in excess of the costs and expenses due from the defaulting party.

Specific performance is equitable relief given by the court to enforce against a defendant the duty of doing what he agreed by contract

\footnotetext{
24 Robinson v. Harman [1848] 1 Exch. 850 at 855, 154 E.R. 363 at 365.

25 Wallis v. Smith (1882) 21 Ch. D. 243 at 257.

2s Trans Trust S.P.R.L. v. Danubian Trading Co. [1952] 2 Q.B. 297 at 307.

27 Id. at 306.
} 
to do. The duty of the defaulting party is to pay. its share of the costs and expenses of the operations. It has been suggested that the damages awarded for the default will not exceed the amount owed by the nonoperator. It might therefore appear that the damages awarded in this instance cannot adequately compensate the operator and thus specific performance might be an appropriate remedy. The court, however, does not seem to take cognizance of the inadequacy of such an award, and specific performance will not be awarded in such circumstances. In any event the imposition of the equitable remedy against a defaulting non-operator to enforce payment of a sum of money would seem to possess no greater advantages than an action for payment of that sum.

\section{INTEREST}

At common law interest is not recoverable for non-payment of money. Section 34(16) of the Alberta Judicature Act ${ }^{28}$ now permits the court to award interest in such an action where it seems "fair and equitable" at such rate as seems "proper." Under the operating agreements provision is normally made for the payment of interest in the event that payment is delayed. The date upon which interest may first be levied varies, though the customary moment is thirty days after the billing of the defaulting party. It may be necessary to issue a notice of nonpayment before interest will begin to accrue under the agreement. The rate of interest charged may be an absolute figure, for example six to eight per cent, or set at a fixed level above the bank rate, for example, one per cent.

The imposition of interest is generally at the discretion of the operator and for the benefit of his sole account.

\section{CONDITIONS UPON AGREED REMEDIES}

The issuing of a notice of non-payment or default, or the communication of a demand for payment, is normally required prior to the invocation of the remedies bestowed upon the operator by the operating agreement in the event of default by a non-operator. The notice may be effective when served, received or merely sent. It may be necessary for a period of default to elapse after such notice or demand, the usual period being thirty days. In the case of the transmitting of a demand for payment such a period would seem to be mandatory in order to allow the non-operator a reasonable time in which to make payment. The remedies expressly established by the operating agreement may empower action against the property of the defaulter, the denial of the benefits of the agreement, or the suspension of operations under the agreement. The efficacy of the remedies has infrequently been examined by the judiciary but it is suggested that they form an essential protection for the operator. The redress available under the general principles of the law of contract is not appropriate to the needs of the managing party in the development and production of oil and gas resources.

\section{RIGHTS RE PROPERTY OF NON-OPERATOR}

\section{The Lien}

At common law a lien is the "right in one man to retain that which is rightfully and continuously in his possession until the present and 
accrued claims of the person in possession are satisfied."29 Such a lien arises by operation of law-by custom or trade usage. The custom in the oil and gas industry may bestow upon an operator a lien at common law. However, "[t]here can be no lien upon any property unless it is in the possession of the party who claims the lien."30 Under an operating agreement an operator is entitled to and is in possession of the joint lands, equipment and production. The lien, of course, could subsist only for so long as the operator remained in possession. The lien would cease to exist when the production left the operator's possession. The feature that dissuades an operator from relying upon its common law right of lien is its limited potency. It is a right of defence only. It does not grant any rights of sale, but merely bestows a passive right of retention until payment. An exceptional right of sale does exist in regard to perishable goods, but it would not appear that oil and natural gas production lies within this category.

An equitable lien is "an equitable right, conferred by law upon one man, to a charge upon the real or personal property of another, until certain specific claims have been satisfied." 31 The lien arises from the relationship of the parties and exists irrespective of possession. Expenditure upon the property of another in the circumstances of a fiduciary relationship may establish an equitable lien upon such property. The costs and expenses incurred by the operator on behalf of the joint account may give rise to an equitable lien enforceable against the property of the non-operators upon which expenditure was made. Such a lien also comes into existence in the event that a partnership is established.

A judicial sale is the method by which an equitable lien is enforced. The court may also appoint a receiver pending a sale. These attributes of the equitable lien might seem attractive to an operator, but they must be balanced against the considerable problems that might be encountered in establishing a proper relationship and the handicap of judicial control of a sale.

A lien arises by operation of law, not by contract. Where a right similar in its characteristics to a lien is created by contract, the contract itself must be examined in order to determine exactly what rights over the property concerned the parties intended to create. The use of the expression in operating agreements is inaccurate, but follows an established practice of using the term "lien" to mean a right of detention less than ownership, in the nature of security for due performance. The contractual provision supersedes the possibility of a lien and limits the rights of those claiming under the agreement to those for which provision has been made in the contract.

The form of the lien stipulated by the operating agreement may be as that found in the A.A.P.L. Operation Procedure, 1970:

Clause 504 Operator's Lien

(a) The operator shall have a lien on the interest of each non-operator in the joint lands and in production wells and equipment therefrom and thereon to secure payment of that non-operator's proportionate share of the cost and expenses of all operations carried on by the operator for that non-operator, but the said lien shall not attach to any portion of any non-operator's share of the petroleum substances produced prior to the enforcement by the operator of the lien as hereinafter provided.

\footnotetext{
2924 Halsbury's Laws 142 (3d ed. Simonds 1955).

${ }^{30}$ Shaw v. Neal (1858) 6 H.L.C. 581 at 601, 10 E.R. 1422 at 1431 per Lord Chelmsford.

II Supra, n. 29 at 149.
} 
(b) ... the operator may:

(iii) enforce the lien created by the default in payment by taking possession of all or any part of the interest of the defaulting non-operator in the joint lands or in all or any part of the production therefrom and equipment thereon; and the operator may sell and dispose of any interest, production or equipment of which it has so taken possession either in whole or in part or in separate parcels at public auction or by private tender at a time and on whatever terms it shall arrange, having first given notice to the defaulting non-operator of the time and place of the sale. The proceeds of the sale shall first be applied by the operator in payment of any costs to be paid by the defaulting non-operator and not paid by it and any balance remaining shall be paid to the defaulting non-operator after deducting reasonable costs of the sale. Any sale made as aforesaid shall be a perpetual bar both at law and in equity against the defaulting non-operator and its assigns and against all other persons claiming the property or any part or parcel thereof sold as aforesaid by, from, through or under the defaulting non-operator or its assigns.

A feature of the lien under the A.A.P.L. agreement is the manner in which it is restricted to a form which might arise at common law. The operator is said to have a lien upon the interest of each non-operator in the joint lands, production and equipment, but the lien is not to attach to the production until possession is taken thereof. Assuming that the operator is already in possession of the joint lands and equipment, it would appear that the lien is based essentially upon the same principle as its common law counterpart-possession.

It is in the method of enforcement that the advantages of the agreed remedy over that which might be implied by operation of law appear. Under the A.A.P.L. agreement the lien is enforced by taking possession of the particular interest of the non-operator and disposing of it upon whatever terms the operator might arrange-having first given notice to the non-operator of the sale. Such a right of sale is far in excess of that bestowed either at common law or in equity. For the purposes of the Alberta Land Titles Act, ${ }^{32}$ the lien upon the interest of the defaulting non-operator in the joint lands is a "mortgage." Section 2(14) defines a mortgage as "any charge on land created merely for securing a debt or loan." Section 2(11) states that "land" includes a mineral lease. It is interesting to consider the similarity between the right of sale under the A.A.P.L. agreement and that formerly drawn up as an express power in a mortgage. As the lien constitutes a mortgage under the Land Titles Act it is registerable provided it was established in the form prescribed by section 104 of the Land Titles Act. The priority of the lien is thus dependent upon the date of registration. Neither equipment nor production comprise "land" under the Land Titles Act, consequently liens upon such property are not registrable. The priority to payment upon the proceeds granted to the operator by the operating agreement would seem to confirm the legal, as opposed to equitable, nature of the interest of the operator.

The declaration that a sale under the lien constitutes a "perpetual bar" to those claiming through the defaulting party to overturn the title would seem to confirm that a good title is bestowed upon the purchaser. The sale is neither a penalty nor a forfeiture and equitable relief could accordingly not be invoked against it.

A contrast to the lien described above, which has been fashioned to the needs of the operator, is that commonly employed which is based

32 R.S.A. 1970, c. 198. 
upon the mechanism by which mechanics' liens are enforced. The provision invariably adopts the following form: ${ }^{33}$

\begin{abstract}
Managing-operator shall have a first and prior lien on all rights and the interest of a joint-operator in and to the lands, the leases and in any production obtained therefrom and material and equipment thereon, to secure the payment by such joint-operator of any amounts owing by it to managing-operator pursuant to the terms of this Agreement. . . . Managing-operator shall have the right to enforce payment thereof ... in the manner in which mechanics' liens are enforced under the applicable statute....
\end{abstract}

The provisions of the appropriate statute are to be applied as they are when the operator comes to enforce the lien. An operator who enforces the lien upon lands within the province of Alberta on April 1st, 1971, will do so in the manner in which mechanics' liens are enforced under the Builders Lien Act 1970.34 The Builders Lien Act establishes a fund for payment to those persons who have provided services or material to property and have thereby improved the value of the land. The lien claimant must register a "lien" against the land of an "owner" at the Land Titles Office. This gives rise to an interest in land similar to a mortgage interest to the extent of a partial value at least of the costs of the services or materials which have been supplied.

The benefit of the Act is intended for those persons involved in construction projects. Particular provision is made for work undertaken by a drilling contractor in oil and gas operations, but essentially the Act is inappropriate for the enforcement of an obligation to pay the costs and expenses of oil and gas drilling and development among the parties to an operating agreement. The non-operator and the operator in the operating agreement establish the manner in which the expenses of development will be borne. The drilling contractor may establish a lien against the "owner" of the joint lands for the costs. The "owner" for the purposes of the Builders Lien Act is the body of the operator and the non-operators. ${ }^{35}$ The operator is not an entity recognized by the Act other than as a constituent of the owner. It is inconceivable that an operator could enforce a lien against a defaulting non-operator under the Builders Lien Act.

The parties to an agreement may delegate increased authority over the manner of enforcement in the event of default to the court. Such addition to the powers of the court is subject to the limitations the court imposes upon itself in exercising them. The parties to the agreement, moreover, cannot alter the rights of enforcement of third parties. In particular the priority mechanism of an otherwise inapplicable statute cannot be imposed by agreement upon a third party. Upon the basis of this statement of principle an attempt will be made to reconcile the provisions of the operating agreement to the Builders Lien Act.

The unique feature of mechanics' or builders' liens is the statutory holdback, that is the requirement that the "owner" retain a certain sum of money to establish a lien fund out of which lien claimants may be paid. The holdback is intended to ensure the payment not of the contractor but of the sub-contractor. If the possible interpretation of the operating agreement is adopted and the non-operator and the operator are placed in a distorted owner-contractor relationship the folly of the

\footnotetext{
33 Supra, n. 6, Clause 10.

34 R.S.A. 1970, c. 14.

35 Id. 8. 2(g) and 8. 4(2).
} 
provisions is revealed. The defaulting non-operator would be required to hold back fifteen per cent of the payment to the operator of costs and expenses to ensure the payment of the drilling contractor. The enforcement mechanism provided by the agreement would involve depriving the operator of the sums of money the payment of which he is seeking to enforce. It is suggested that the unfortunate effect of such an implication coupled with the apparent denial of the concept of a holdback by the payment provisions of the agreement, exclude this aspect of the Builders' Lien Act.

The lien is stated by the operating agreement to extend to "all rights and interest of a joint-operator in and to the lands, the leases and in any production obtained therefrom and the material and equipment thereon." Under the Builders' Lien Act a receiver may be appointed for the rents and profits of the property against which a lien is registered or a trustee may be appointed with yet wider powers. Such powers would only be invoked under the Act if the owner had failed to maintain a lien fund since under section 18 payment into court of the lien fund has the consequence that the "money stands in the place of the land." It is clear that it is not intended that a lien fund should exist under the operating agreement so it is suggested that the court would have the power to make such appointments if an action was brought to enforce the lien. The Act makes provision for a right of sale in section 45(3):

When the court orders a sale, the court may

(a) direct that the sale take place at any time after the judgment, allowing a reasonable time for advertising,

(b) direct what advertising of the sale is required, and

(c) make all necessary orders and directions for the completion of the sale and the resting of the estate or interest in the purchaser.

The operator, it is submitted, might possess a similarly restricted right to enforce a sale. It would seem that the operator must bring a court action to enforce the powers attaching to the lien.

The suspicion that surrounds the peculiar attributes of the lien created by the operating agreement is that they cannot bind a person who is not a party to the agreement. This is emphatically demonstrated in the determination of priority as to charges upon the property subject to the lien. The operator's lien is a mortgage within the definition of section 2(14) of the Land Titles Act if drawn up in the prescribed form. Thus priority as to payment out of the proceeds of the defaulting nonoperator's interest in the joint lands is dependent upon the date of registration.

Investigation among members of the oil and gas industry as to the efficacy of this form of operator's lien reveals that it has never been tested in court in Canada. Furthermore no insight was obtained as to how an operator might go about enforcing the lien "in the manner in which mechanics' liens are enforced under the applicable statute." It is suggested that it is a provision culled directly from American agreements. The model of the mechanics' lien is conceptually inappropriate as that right is designed to protect those out of possession of property, for example suppliers of building materials. The operator is in possession of the defaulting non-operator's interest in the joint lands and equipment. A more suitable remedy might be readily drawn up bestowing a right of sale of the non-operator's interest in the joint property upon the operator. 
2. Assignment of Proceeds of Non-operator's Share of Production

The defaulting non-operator, though he has failed to pay the costs and expenses due from liens, may be deriving large sums of money from the purchaser of his share of production. The proceeds may be the most readily accessible fund from which the operator might seek payment. In order to allow access to the proceeds, operating agreements generally provide that an operator may unilaterally assign the fund to the benefit of the operator in the event of default by a non-operator. The terms of the agreement are likely to take the form of one of two varieties: ${ }^{36}$

... the operator may

... treat the default as an immediate and automatic assignment to the operator of the proceeds of the sale of the non-operator's share of the petroleum substances; and from and after the operator making such election, the operator may require the purchaser of the non-operator's share of the petroleum substances to make payment therefore to the operator while the default continues....

... the operator may:

... by notice accompanied by a copy of this agreement to any purchaser of the joint-operator's share of production, require such purchaser to pay to the managingoperator the proceeds of such share of production which shall be applied toward the payment of the amount unpaid and the managing-operator is hereby constituted irrevocably the attorney of the joint-operator for the purpose of executing the instruments necessary to effect an assignment of such proceeds.

An assignment of a legal chose in action may be effective under statute or in equity. The requirements of a statutory assignment are laid down in section 34(15) of the Alberta Judicature Act: 38

(15) Where a debt or other legal chose in action is assigned by an absolute assignment made in writing under the hand of the assignor and not purporting to be by way of charge only, if express notice in writing of the assignment has been given to the debtor, trustee or other person from whom the assignor would have been entitled to receive or claim the debt or chose in action, the absolute assignment is effertual in law to pass and transfer

(a) the legal right to the debt or chose in action from the date of the notice of the assignment,

(b) all legal and other remedies for the debt or chose in action, and

(c) power to give a good discharge for the debt or chose in action without concurrence of the assignor,

and is subject to all equities that would have been entitled to priority over the right of the assignee if this subsection had not been enacted.

It appears that the form of agreement which irrevocably constitutes the operator an attorney for the purpose of the assignment and requires express notice to the purchaser of the production is an effort to comply with the statute. The assignment of the proceeds is, however, limited to the payment of the amount unpaid. In the other form of agreement the assignment continues only as long as does the default. The statute lays down that the assignment must be absolute and not by way of charge only. This requires that the assignor must part with its entire interest in the property. Assignment of part of a debt is not an absolute assignment within the subsection: to be absolute, the assignment must extend to the whole fund. ${ }^{39}$ Thus it would seem that assignment of the proceeds of production until the default is rectified cannot benefit from the advantage of statutory assignment.

\footnotetext{
${ }^{36}$ Supra, n. 15, Clause 504(b)(ii).

37 Supra, n. 3, Clause 1207.

$3 s$ Supra, n. 28.

39 See Re Steel Wing [1921] 1 Ch. 349.
} 
In equity an assignment merely requires a clear intention to assign. No special form is necessary. The operating agreement may be said to comprise the intention required. While the assignment is in equity complete from the standpoint of the assignor and assignee without notice to the debtor (purchaser of production), it does not bind the debtor until he has notice of the agreement, so that if he pays the assignor before he obtains notice, he obtains a good discharge.40 An assignment of the proceeds under the provisions of the operating agreement cannot bind the purchaser until he has received notice. The operator must therefore ensure that the purchaser is given notice as rapidly as possible, a stipulation that forms one element of the process under one form of operating agreement.

The requirement of notice to the purchaser is important in determining priorities. The priority of successive assignees in equity of a chose in action depends upon what is generally known as the rule in Dearle v. Hall.41 The rule may be stated thus: "where there are successive assignments in equity of a chose in action, the priority of assignees is determined prima facie by the order in which the assignees gave notice of the assignment to the debtor, and not by the order in which the assignments were made." 42 If the defaulting non-operator has assigned the proceeds prior to the assignment to the operator, in an effort to escape its financial difficulties, then the operator's claim may be postponed to the prior assignee if the latter has given notice to the purchaser.

Equitable assignments have always been subject to all equities, that is all defences which could be raised in respect of the chose against the assignor can be raised also against the assignee, provided that the matters upon which they are based occurred before the assignment. Such a defence might be a right of set-off that arose prior to the receipt of notice by the purchaser. The defence would extend to loans made to a non-operator to finance development, even if made after notice of the assignment if the advances were made under an agreement reached before notice.

An equitable assignment is not defeated by a requirement that it be "absolute . . . (not purporting to be by way of charge only)." It is effective to transfer a right of action in equity provided there does exist a specified fund out of which payment is to be made. The proceeds of the defaulting non-operator's share of production afford such a fund. The less stringent requirements of an assignment in equity correspond to the greater obstacles in its enforcement under statute. The assignment in equity may be effective in requiring a purchaser to pay the proceeds to the operator, but if the operator is to give the purchaser a good discharge the defaulting non-operator must be joined in.

\section{Forfeiture}

The most damaging remedy devised for the benefit of the operator is the forfeiture of the defaulting non-operator's interest in the joint lands and jointly owned property. The property vests in the operator. The operating agreement terminates as regards that non-operator and it

\footnotetext{
${ }^{40}$ See London and Yorkshire Bank (Ltd.) v. White (1895) 11 T.L.R. 570.

4 (1823) 3 Russ, 1, 38 E.R. 475.

“2 Keeton on Equity 301 (1969).
} 
is discharged from the liability for debts to the operator. The provision in the agreement may take the following form:

\begin{abstract}
... the managing-operator may: . . . if, in the opinion of the managing-operator, the joint-operator will be unable to satisfy its obligations hereunder within a reasonable time, by notice to the joint-operator require payment in full of the unpaid amount within ninety (90) days from the date of the notice and in default of such payment within the said period the joint-operator's interest in the joint lands and the jointly owned property shall thereupon vest in the managing-operator in consideration for which the joint-operator's obligation to pay the unpaid amount shall be extinguished and this agreement shall terminate as to the joint-operator in default, except that the joint-operator shall execute and deliver to the managing-operator the instruments necessary to give effect to this sub-clause.
\end{abstract}

The accrual of the power and the nature and extent of the rights of a party properly exercising an express power of forfeiture fall to be determined by the express terms of the contract. Clauses will normally be strictly construed in determining whether the operative event, upon which the power depends, has occurred.

A power of forfeiture will be wrongfully exercised if one of the events upon which it is conditioned has not occurred. It is, therefore, essential that the operator does honestly consider that the non-operator will be unable to meet its obligations under the agreement within a reasonable time. Further, if by the terms of the agreement, notice must be given to the party in default and a period allowed for its rectification, the power may only be invoked if the requirements are satisfied. A period of ninety days is generally specified in the operating agreement.

Although the circumstances may have occurred upon which the right to forfeit arises under the terms of the agreement, the operator may be precluded from enforcing the forfeiture if he has, by his own actions, rendered it inequitable that he should do so. The rule of law might apply which exonerates the non-operator from the performance of the agreement, where the performance of it is prevented or rendered impossible by the wrongful act of the operator. ${ }^{43}$ If the operator withheld considerable sums of money due to the non-operator under the agreement a subsequent exercise of the right of forfeiture would be wrongful: 44

... each of the parties to a contract is under a general duty to allow the other to carry out his obligations under it; and the purported exercise of a power of forfeiture by one who has not performed his duty in that respect will be wrongful, since no man can take advantage of his own wrong.

If the power of forfeiture is validly exercised then the defaulting non-operator will be deprived of its interest in the joint property unless the court is prepared to grant relief. Relief is governed in Alberta by section 32(o) of the Judicature Act:

In every civil cause or matter commenced in the Supreme Court, law and equity shall be administered by the Court according to the following rules:

(o) subject to appeal as in other cases, the Court has power to relieve against all penalties and forfeitures and, in granting such relief, to impose such terms as to costs, expenses, damages, compensation and all other matters as the Court sees fit.

In the recent case of Popyk v. Western Savings and Loan Association ${ }^{45}$ the nature of "forfeiture" under section 32(o) was discussed in the Ap-

\footnotetext{
3 See Roberts v. Bury Improvement Commissioners (1870) 5 C.P. 310.

"Hudson, Building Contracts 402.

is (1969) 67 W.W.R. 684.
} 
pellate Division of the Supreme Court of Alberta. McDermid J.A. delivered the following remarks: 46

Forfeiture is defined in Jowitt's Dictionary of English Law: 'Forfeiture is where a person loses some property, right, privilege or benefit in consequence of having done or omitted to do a certain act.'

In Williston on Contracts, 3rd Ed., Vol. 5, it is stated at 640:

'Although the words forfeiture and penalty are often used as synonyms, the word forfeiture carries an implication of something previously owned as distinguished from subjection to a liability, but the distinction is often blurred. . . In Empire Loan and Savings Co. v. McRae (1903) 5 O.L.R. 710, Britton J. said at 711 . 'Forfeiture is penalty for breach of duty, or breach of contract ... although in the agreement no such word as penalty or forfeiture is found.'

The issue as to whether the forfeiture of the non-operator's interest in the joint property is a "forfeiture" for the purposes of the Judicature Act is a live problem. In two cases which have considered a similar question no satisfactory conclusion was reached.

In Wetter v. New Pacalta Oils ${ }^{47}$ action was brought for a declaration that a petroleum lease was null and void. The lease provided for forfeiture in the event that no well had begun to be drilled by a certain date. O'Connor C.J.A. in delivering judgement, stated:48

I refrain from expressing an opinion on the question of whether what has been called the forfeiture clause, in this and other similar agreements for the drilling of oil wells, provides a "forfeiture" against which the Court has, under the Judicature Act ... power to relieve, or whether, by reason of the conditions which prevail, time must not be considered so much of the essence that the clause works an automatic termination of the rights of the defaulting operator.

The learned judge drew a distinction between a breach of a condition subsequent and a clause specially delineating the interest of the defaulting operator. The distinction would not seem applicable outside a lessor-lessee relationship, but O'Connor C.J.A. adopted it again in Oil City Petroleums (Leduc) Ltd. v. American Leduc Petroleums Ltd. ${ }^{49}$ The defendants, owners of oil leases, entered into a trust agreement with the plaintiffs, oil operators, with a view to the development and oil production of the lands leased: The plaintiffs were to receive a share in the gross proceeds of oil production. The plaintiffs defaulted under the agreement in failing to commence the drilling of a well within the time specified. The agreement provided that in the event of such default by the operator the owners might, at their option, terminate the agreement. On the exercise of this option the plaintiff applied for relief against forfeiture.

In the Appellate Division of the Supreme Court of Alberta all five judges agreed in dismissing the plaintiff's claim. But Frank Ford J.A. and Parlee J.A. concurred with the reservation imposed by O'Connor C.J.A., in which the learned judge repeated the reasons given in the Wetter case for refusing to decide whether the cessation of the rights of the operator constituted a "forfeiture" for the purposes of the Judicature Act.

Clinton Ford J.A. (MacDonald J.A. concurring) concluded that the termination of the agreement was a "forfeiture", but dismissed the problem in the following terms: ${ }^{50}$

\footnotetext{
4 Id. at 689 .

47 (1951) 2 W.W.R. (N.S.) 290.

48 Id. at 294.

49 [1951] 3 D.L.R. 835.

so Id. at 842.
} 
If there is no forfeiture involved, that is the end of the case; but, assuming that there is, which is the view I hold....

As to the nature of the interest of the operator the learned judge commented: 51

... the agreement gave it the right to participate in the gross proceeds of the production of any commercial well produced on the leased premises, and the leases were held in trust for this purpose. In my view, this created an equitable interest in the leases for the benefit of the plaintiffs.

In the Wetter case it seems that O'Connor C.J.A. was unwilling to decide whether the particular clause amounted to a special limitation upon the interest of the operator. In the later case the problem was whether or not the operator did possess an interest arising from the operating agreement, and if so did the clause constitute a special limitation upon it.

An operating agreement does not originate the interest of a nonoperator, as was the case in Oil City v. American Leduc. ${ }^{52}$ Nor would it appear that an operating agreement can impose a special limitation upon the interest of a party to that agreement. Rather it may bestow a condition subsequent on the holding of such interest. The objections raised by the two cases to the application of section 32(o) in the event of the invocation of the forfeiture clause in the operating agreement do not seem appropriate.

The extent of the power to award relief against forfeiture under the Judicature Act has been the subject of considerable judicial discussion. In Royal Trust Co. v. Bell, Beck J., as he then was, commented on the subsection now referred to as section $32(0): 53$

This provision goes much beyond the statutory provisions conferring jurisdiction upon the Courts of England.

Some years later in Snider v. Harper ${ }^{54}$ the Appellate Division of the Supreme Court of Alberta followed Royal Trust Co. v. Bell and held that it could relieve against all forfeitures arising from breaches of covenants in a lease. During the course of the judgement Stuart J.A. commented: 55

The section speaks clearly of 'all penalties and forfeitures' without limitation and I have no doubt that, the Court being given by statute a certain power, it ought to exercise that power whenever it deems it just and equitable that it should do so.

In Risvold and Mallory v. Scott and Granville Oils, ${ }^{56}$ Snider v. Harper was accepted as an authority and the judge was prepared to award relief against the forfeiture of an oil and gas lease. The significance of the case may be appreciated in the light of the notion that the leaseholder of an oil and gas lease is possessed of a profit a prendre. In Risvold v. Scott, Ewing J. appears to have recognised no difficulty in applying the criteria of Stuart J.A. despite the different interest concerned.

The ability of the court to award relief against forfeiture in the circumstances of the oil and gas industry has been most fully discussed in

\footnotetext{
si Id.

32 Supra, n. 49.

s3 [1909] 12 W.L.R. 546 at 550 .

st [1922] 2 W.W.R. 417.

ss Id. at 419

so [1938] 1 W.W.R. 682.
} 
Oil City v. American Leduc. Clinton Ford J.A. expressed his approval of the comments of Stuart J.A. in Snider v. Harper and conducted an examination of the few cases that have arisen in regard to relief against forfeiture in the oil and gas industry.57 The learned judge concluded that consideration of an award of relief against forfeiture must take place upon the facts and circumstances of a particular case: ${ }^{88}$

$\ldots$ in the light of the object sought to be achieved by the parties to the contract; and having regard, also to the nature of the oil production business with pressure being constantly exerted in pushing forward oil-drilling operations.

On the facts of Oil City Petroleum v. American Leduc Petroleum, Clinton Ford J.A. determined that, as the time for the commencement of drilling was of the essence of the contract, as the plaintiff's prospects of performing had deteriorated and as the well was in a wildcat field where the property rights at stake were speculative, an award of relief should not be made.

In the Supreme Court of Canada ${ }^{59}$ the decision was affirmed, though the jurisdiction of the court to award relief was not considered. Kellock J. commented: 60

With respect to the contention that the appellants should be relieved from the consequences of their default, I see no ground, assuming but without deciding there is jurisdiction to do so, upon which relief should be granted.

Among the recent cases that have examined the criteria upon which an award of relief against forfeiture will be granted outside the oil and gas industry, is the case of Dimensional Investments Ltd. v. The Queen $^{61}$ decided by the Supreme Court of Canada. The appellant company arranged to purchase Indian lands which had been surrendered to the Crown for sale on behalf of the Indians. The price was $\$ 6,521,946$ to be paid by instalments over a period of two years. So long as the appellant was not in default, it was entitled to obtain grants of portions of the land on making certain additional payments calculated on the property to be conveyed. The last payment $(\$ 4,198,549)$ required under the agreement was not paid. The contract contained a clause stipulating that time was of the essence and that upon default the Crown could terminate the contract and retain "any moneys paid under this agreement as liquidated damages and not as a penalty." The Crown having terminated the contract, the appellant, by its petition of right, sought to recover the moneys which it had paid in excess of what it had been required to pay for land which it had been granted.

In the Exchequer Court ${ }^{62}$ Mr. Justice Thurlow concluded that, but for section 48 of the Exchequer Court Act $^{63}$ he would have granted relief from forfeiture as he was of the opinion that the Crown's retention of the moneys as well as the lands was "unconscionable". The basis of the trial judge's decision was the judgement delivered in Stockloser v. Johnson ${ }^{64}$ in the Court of Appeal in England where Romer L.J. suggested that "in the absence of some special circumstances, such as fraud,

\footnotetext{
57 [1951] 3 D.L.R. 835 at 842.

so Id. at 843 .

so [1952] 3 D.L.R. 577 .

so Id. at 580.

o1 [1968] S.C.R. 93.

22 [1966] Ex C.R. 761.

$\omega$ R.S.C. 1952, c. 98.

at [1954] 1 Q.B. 476.
} 
sharp practice or other unconscionable conduct of the vendor" no intervention to grant relief was permissible except to allow an extension of time for payment. Somervell and Denning L.J.J. on the other hand, thought that the province of equity was not so circumscribed and that it permitted more general relief whenever the forfeiture clause was of a penal nature-provided that in the circumstances it was unconscionable for the money to be retained.

In the Supreme Court it was decided that it was not unreasonable to view the default clause as reflecting a genuine pre-estimate of damage to which both parties had agreed; accordingly it was not a penalty clause. Ritchie J., delivering the judgement of the Court, cited the judgement in the Stockloser case approvingly, but did point out the reservation made by Lord Radcliffe in Bridge v. Campbell Discount that: 65

'Unconscionable' must not be taken to be a panacea for adjusting any contract between competent persons when it shows a rough edge to one side or the other, and equity lawyers are, I notice, sometimes both surprised and discomfited by the plentitude of jurisdiction, and the imprecision of rules that are attributed to 'equity' by their more enthusiastic colleagues.

The learned judge stressed that the "question of unconscionability must depend upon the circumstances of each case at the time when the clause is invoked".66 In the still more recent case of Popyk v. Western Savings and Loan Association ${ }^{67}$ the concept of unconscionability was applied to the retention of a deposit on the purchase of a savings investment certificate. The judgement of Ritchie J. in Dimensional Investments v. The Queen ${ }^{68}$ must be regarded as the most authoritative exposition of the principles upon which an award of relief from forfeiture may be granted in Canada. It was, however, delivered in a context alien to the oil and gas industry. The judgement of Clinton Ford J.A. in Oil City v. American $L e d u c^{69}$ provides a suggestion as to how far the special interests of the industry will alter the principles upon which relief may be awarded.

The position of a defaulting non-operator is, however, different from that of an operator in breach of an obligation to drill examined in Oil City v. American Leduc. The default by the non-operator is not an impediment to the oil production business of so serious nature as the default by the operator. The breach of the non-operator may be considered "in the light of the object sought to be achieved by the parties to the contract." The operating agreement seeks to establish the terms upon which the parties might drill for and develop oil and gas resources upon a joint basis, each party bearing a proportion of the cost. But the forfeiture under the agreement must be examined in light of the circumstances prevailing at the time the clause is invoked to determine the question of unconscionability. It may be that no matter how a forfeiture clause is drawn up, if the amount forfeited is wholly disproportional to the damages suffered, the clause may not avail an operator if the non-operator seeks relief from the court.

The corrective period of 90 days after notice provided by the agreement, during which time the non-operator may make good the default,

4.5 [1962] A.C. 600 at 626.

66 Supra, n. 59 at 101.

67 Supra, n. 45.

68 Supra, n. 61.

Supra, n. 49 
may disincline the court to grant relief. The non-operator may be considered to have submitted to the stipulated time as adequate for the rectification of his default. However it is suggested that the intention of the parties at the time the agreement is entered into bears only an indirect relationship to the "circumstances . . . at the time when the clause is invoked."

\section{Set-off}

The operating agreement may enable the operator to lay hold of funds of the defaulting non-operator which are in his possession. To this end the agreement may bestow a general right of set-off on the operator: 70

... operator may ...

... set-off against the amount unpaid sums due or accruing to the non-operator from the operator.

The application of the right of set-off would seem to be confined to the situation where a defaulting non-operator fails to take his share of production in kind under the agreement. In such an instance provision is often made that the operator may sell the non-operator's share of production: ${ }^{71}$

If, and for so long as, non-operator fails to take in kind or separately dispose of its share of the petroleum substances as produced, or if it so directs operator, operator shall have the right to dispose of non-operator's share of the petroleum substances at the same price and on the same terms as operator receives for its own share of such petroleum substances or at such prices as operator, acting as a reasonably prudent operator, and having regard to current market prices, availability of markets and economic conditions affecting the petroleum industry generally, would dispose of its own share of such petroleum substances.

\section{WITHDRAWAL OF BENEFITS OF AGREEMENT}

The sanctions available to the operator against a non-operator in default extend to the withdrawal of benefits of the agreement beyond its interest in the joint lands, equipment and production. The most common form entails the exclusion of the non-operator from knowledge of information obtained during operations. The clause may be phrased: ${ }^{72}$

... the operator may

... withhold from the non-operator any further information and privileges with respect to operations."

... the operator may

. . . withhold all information to which non-operator would otherwise be entitled.

The danger in exercising the sanction is that an operator may thereby commit a breach of the fiduciary duty owed to the non-operator.

The majority of the Supreme Court in Midcon Oil and Gas v. New British Dominion Oil ${ }^{74}$ seem to have been content to confine the search for the duty owed by the operator to the non-operator to the terms of the agreement. However Rand J.'s dissenting judgement disputed this approach. The learned judge has subsequently been supported by the decision in Manning v. Calvan Consolidated Oil and Gas. ${ }^{75}$ There the

\footnotetext{
70 Supra, n. 17, Clause 501(5)(a).

"Id., Clause 901.

72 Supra, n. 15, Clause 504(b)(i).

73 Supra, n. 17, Clause 501(5)(d).

74 [1958] S.C.R. 314.

${ }^{75}$ See 1 Lewis \& Thompson, Canadian Oil and Gas, Div. B, Digest 183 and 224.
} 
agreement concerned was not an operating agreement. It provided for an exchange so as to establish the co-ownership of undivided interests in certain drilling permits. Part of the terms were embodied in a letter from Manning:

This will confirm the arrangement we have made with respect to B.C. permit 153, which I hold in my name, and Permit 120 which is in the name of Calvan Consolidated Oil and Gas Co. In principle, I am trading Calvan Consolidated Oil and Gas Co. $20 \%$ in return for $20 \%$ of Permit 120 .

It is agreed that you are to have the right to dispose of, or deal with Permit 120 on behalf of us both in such manner as you see fit....

McLaurin J. held, in the Alberta Supreme Court, that Calvan Consolidated was in breach of fiduciary duty in making a farmout agreement concerning Permit 120 as part of a package deal including other permits solely owned by Calvan Consolidated, under circumstances where a conflict of interest might arise. In particular the farmout agreement provided for the transfer of drilling credits to the soley-owned permits. The learned judge commented:76

The contract should be looked at as one in which Calvan used joint property to secure a special advantage for itself. Accordingly, I hold that the provision as to drilling credits amounts to breach of trust.

McLaurin J. cited the statement of Viscount Sankey in Regal (Hastings) $L t d$. v. Gulliver in support of his conclusion: ${ }^{77}$

The general rule of equity is that no one who has duties of a fiduciary nature to perform is allowed to enter into engagements in which he has or can have a personal interest conflicting with the interests of those whom he is bound to protect.

Reconciliation of the Manning case to Midcon v. New British is not simplified by the lack of consideration given by McLaurin J. to the existence of a fiduciary relationship. It seems that the learned judge did not feel that the authority bestowed upon Calvan to act in the matter as it saw fit in any way diminished the fiduciary element in the relationship. The fiduciary concept was employed to place considerable restraint on the exercise of this right provided by the agreement. It seems that the rejection of a fiduciary relationship in the Midcon case by contrast, enabled the court to limit the burden of duties imposed upon the operator to those stipulated in the agreement.

The extent to which the fiduciary relationship colours the actions of the fiduciary must be considered in the light of the decision in Boardman v. Phipps. ${ }^{78}$ There Lord Hodson remarked: ${ }^{79}$

The proposition of law involved in this case is that no person standing in a fiduciary position, where a demand is made upon him by the person to whom he stands in the fiduciary relationship to account for profits acquired by him by reason of his fiduciary position and by reason of the opportunity and the knowledge, or either, resulting from it, is entitled to defeat the claim upon any ground save that he made profits with the knowledge and assent of the other person.

Maudsley, in the ninth edition of Hanbury on Equity, suggests that such a proposition requires the "full disclosure and the obtaining of the consent of the other parties." 80 The opportunity for profit must, of course, have arisen by reason of the fiduciary situation of the party. ${ }^{81}$

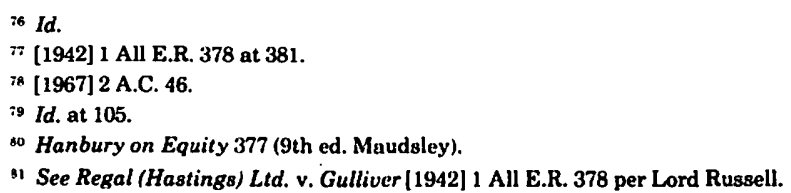


In Pine Pass Oil and Gas v. Pacific Petroleums $L t d .{ }^{82}$ the scope of the fiduciary duty of an operator with regard to information was examined. The court decided that although the operator occupied a fiduciary position qua the plaintiff and had used information coming to it by reason of that position, the plaintiff had no ground for complaint. By the terms of the agreement the plaintiff had forsaken its right to share the information except on its undertaking to convert its carried interest into a participating interest, which it had not applied to do. The judge stated:83

I cannot accept the proposition that the defendant increased its burden by inserting a clause in the agreement which kept the plaintiffs from access to this information. The plaintiff executed this contract voluntarily and in so doing avoided the risk and cost of carrying on as a joint operator rather than retaining the position of a carried interest holder. Its exclusion from information was a matter of its own choice which could be remedied merely be electing to convert to the status of participating holder. If not entitled to the information, then the plaintiffs should not receive the fruits from the use of such information.

The learned judge reached this conclusion after examining Midcon v. New British in which he considered, somewhat inaccurately, that a fiduciary relationship was established. He stated:84

To maintain the continuing fiduciary relationship with a continuing duty to share and account, the plaintiffs must establish a trust status that extends beyond the express trust. I find in this case they have been unable to do so ...

In the cases stated by counsel for the plaintiffs [Manning v. Calvan Consolidated] the trustee was, by virtue of his position, a continuing trustee such as a solicitor or trustee of an estate. Here, the status or relationship was specified by the terms of the contract. In those other cases again, the trustee was dealing with the trust property, he was dealing with the very property which was the subject of the trust. Here, the defendant was carrying on the same sort of activity, but he was doing it outside of the trust relationship. This was the same situation which existed in the Midcon case, where Locke J. [rejected the application of the rule in Keech v. Sandford].

The suggestion that emerges from the judgements delivered in these cases is that a fiduciary duty of sorts will arise under an operating agreement. The extent of the duty may be limited to a burden of acting in good faith. ${ }^{85}$ If, however, the property concerned forms the subject matter of the agreement the burden imposed upon the operator of showing that it did not act in breach of fiduciary duty will be very much greater. In particular the operator may not escape liability by appealing to the terms of the agreement. ${ }^{86}$ Rather he may be required to undertake a full disclosure and obtain the ratification of the non-operator ${ }^{87}$ The influence of Rand J.'s dissenting judgement in Midcon v. New British may stimulate the attachment of fiduciary liability outside this narrow area.

The validity of the operator's right to withhold information from a defaulting non-operator must be examined in the light of this commentary. The significant fact to be determined appears to be whether information under an operating agreement is sufficiently connected with the scope of his duties as a fiduciary to warrant the attraction of fiduciary

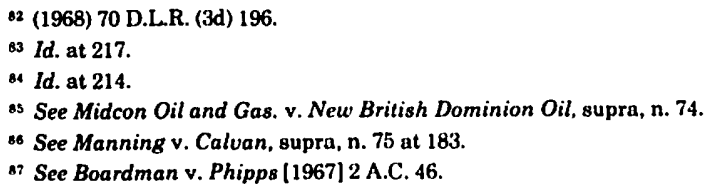


liability, in particular whether it forms the subject-matter of the agreement. In this regard Lord Cohen in Boardman v. Phipps stated:88

Information is, of course, not property in the strict sense of the word and, as I have already stated, it does not necessarily follow that because an agent acquired information and opportunity while acting in a fiduciary capacity he is accountable to his principals for any profit that comes his way as the result of the use of that information and opportunity. His liability to account must depend on the facts of the case.

If an agreement was entered into primarily in order to obtain information upon the geophysical characteristics of adjacent land in view of a forthcoming Crown sale then, it seems, the operator might only withhold the information at the risk of incurring fiduciary liability. An operator might be compelled to hold benefits obtained from such information on constructive trusts for the non-operator.

\section{SUSPENSION OF OPERATIONS}

... the operator may

... suspend operations for the joint account and charge the non-operator with all the costs resulting solely from the suspension.

It has been suggested that mere delay by the non-operator in making payment may not entitle the operator to repudiate the agreement unless time is regarded as being of the essence. The contractual right to suspend joint operations is thus a valuable protection to the operator to ensure that he is not compelled to continue operations, or else be in breach of contract, despite the insolvency of the non-operator. The provision in the agreement entitles the operator to "charge the non-operator with all costs resulting solely from the suspension." Such damages would not be available at common law. ${ }^{89}$

Elsewhere the suggestion has been made that in the event of such suspension the operator is required to hold information obtained during that period on trust for the non-operator until such time as he is fully reimbursed.90 Operations may be conducted after suspension upon the sole account of the operator and the other non-operators. The rights and duties arising in such an undertaking are to the exclusion of the defaulting non-operator. As the operator is no longer acting as the operator in joint-operating vis-a-vis the defaulter it cannot be said to incur fiduciary liability to that non-operator. The operator no longer has a fiduciary relationship to the non-operator with respect to information obtained after the suspension. Such property cannot be said to lie within the scope of the operator's duties as a fiduciary. A contrary view might favour the creation of a continuing fiduciary relationship extending to such information as suggested previously under withdrawal of benefits of agreement.

\section{CONTRIBUTION AND SUBROGATION}

The rights of the operator against the defaulting non-operator are not the exclusive manner by which it might be reimbursed for the costs and expenses incurred. Provision is normally made in operating agreements for contribution by other non-operators who may be subrogated to the rights of the operator against the defaulter:91

8 Id. at $102-3$.

s9 See discussion supra at 294

0 See MacWilliam, Fiduciary Relationships in Oil and Gas Joint Ventures, (1970) 8 Alta. L. Rev. 233 at 245.

21 A.A.P.L. Operating Procedure, 1970, Clause 505; see also Model Unit Operating Agreement, 1966, Clause 1208. 
If the operator has not received full payment of a non-operator's share of the costs and expenses of operations hereunder within three months following the date the payment was due, each non-operator shall, upon being billed therefor by operator, contribute a fraction of the unpaid amount, excluding interest thereon, having as its numerator the participating interest of that non-operator and as its denominator the aggregate participating interests of all parties hereto except the defaulting nonoperator; and thereupon each contributor shall be proportionately subrogated to the operator's rights pursuant to (actual clause in agreement setting down operator's remedies) ...

Contribution is based upon principles of natural justice. Payment by one party liable releases the others from the principal demand, and they are required to contribute as a return for this benefit. But, apart from contract, the principle does not apply unless all the parties are liable to a common demand and such liability is therefore a condition of contribution. The parties to an operating agreement contract on the basis of stipulations that joint liability will not attach. The efficacy of such a provision has been discussed previously, ${ }^{92}$ but its presence explains the need for a clause establishing the right of the operator to claim contribution from other non-operators.

The clause provides that no non-operator shall bear more than its due proportion of the amount claimed by the operator, and that the latter should bear its share in the same fashion. The operator cannot claim interest from the contributing non-operators. A non-operator who contributes payment of costs and expenses under the clause is entitled to the remedies available to the operator to enforce payment by the defaulter of so much as the non-operator has contributed, that is he is subrogated to the rights of the operator.

\section{CONCLUSION}

The operator's remedies provided in joint operating and unit operating agreements have not reportedly been the subject of court action in Canada. Along with the dearth of scholarly material dealing with this area this might seem to suggest that few problems are encountered by operators in enforcing the remedies at their disposal. It would not, however, be correct to suppose that this is a consequence of the manner in which the matter has been handled by those drafting operating agreements. Rather, the lucrative nature of and the large size of the companies involved in the oil and gas industry in Western Canada minimize the likelihood of a non-operator suffering financial difficulties. It is suggested that as profit margins decrease attention will be focused on this area, and the agreements may be the subject of considerable concern by those who in times of high profits entered into them.

The nature of the subject-matter of this article necessitates the application of principles of common law and statute to clauses found in operating agreements. In order to discern the significance of any item in such clauses a knowledge of how oil and gas operations are conducted is required. This article may founder because of a lack of appreciation of the importance of a particular factor in the drilling for and development of oil. Having registered this reservation, it is suggested that the provisions of operating agreements, stating the remedies of which an operator is possessed in the event of default by a non-operator, are bereft of distinctive characteristics to the degree found elsewhere 
in "Oil and Gas Law". The impact of the physical mechanics of oil and gas operations on this area of the law has been minimal.

An evaluation of the remedies available to an operator in the absence of those stipulated by the operating agreement reveals their inadequacy. An award of damages or the repudiation of the agreement cannot prevent the incurring of loss for which an operator will not be fully compensated, nor may oil and gas operations proceed as originally intended. The remedies granted to the operator by the operating agreement seek to avoid these consequences by ensuring generous compensation to the operator. The remedies stipulated by the agreement are subject to the scrutiny of the court, in particular as to the awarding of relief against forfeiture and as to infringements of the fiduciary duty owed to the non-operator by the operator. The obstacles to the enforcement of the operator's remedies presented by the court are to be expected, but there would seem to be little excuse for those casually created by the draftsmen of the agreements. Attention is drawn in this regard to the provision referred to as the "operator's mechanics' lien". The lack of consideration bestowed upon such a clause is manifest.

Insofar as the remedies afforded an operator by an operating agreement have not been contested, there would seem to be little cause for concern. It is felt, however, that the absence of litigation should not in these circumstances be taken as an indication that an evaluation of the clauses involved would not be rewarding. Deficiencies, and a lack of awareness of such deficiencies, are readily revealed in this area. Efforts to improve the protection of the operator, in recognition of the faults exposed by a limited examination of the nature here conducted might be the least that could be undertaken. 